\title{
Effects of Seeding Rate and Sowing Date on Herbage Dry Matter and Seed Yield Performance of Brachiaria Grass Grown under Subhumid Climatic Conditions of Western Oromia, Ethiopia
}

\author{
Mekonnen Diribsa* Waqgari Keba Abuye Tulu Warku Temesgen \\ Oromia Agricultural Research Institute, Bako Agricultural Research Center, P.O.Box 03, Bako, Oromia, \\ Ethiopia
}

\begin{abstract}
The experiment was conducted at Bako Agricultural Research Center (BARC) for three years (2013, 2014 and 2015) to compare the effect of sowing dates and seeding rates on productivity of Brachiaria decumbens. The treatments consisted of four sowing dates ( 1 week, 3 weeks, 5 weeks and 7 weeks) after onset of main rain and four levels of seeding rates $\left(6,8,10\right.$ and 12) $\mathrm{kg} \mathrm{ha}^{-1}$. Accordingly, sowing dates started on May 28, 2013 and thereafter at 14-days intervals: June 11, 2013; June 25, 2013 and July 09, 2013. An experimental design of a randomized complete block in factorial arrangement with three replications was used. The analysis of variance indicated that seeding rate by planting time interaction effect was highly significant $(\mathrm{p}<0.01)$ for herbage DM yield and seed yield. However, none significant differences were observed for plant height, plot cover and vigorousity. The highest herbage dry matter yield and seed yield (18.67 ton ha $\left.\mathrm{h}^{-1}\right)$ and $\left(6.37 \mathrm{Qt} \mathrm{ha}^{-1}\right)$, respectively were obtained from seeding rate of $6 \mathrm{~kg} \mathrm{ha}^{-1}$ that planted at three weeks after the commencement of main rainy season. Year have also significant $(\mathrm{p}<0.01)$ effect on both herbage dry matter and seed yields. Maximum herbage dry matter yield $\left(22\right.$ ton $\left.\mathrm{ha}^{-1}\right)$ and seed yield $\left(9.76 \mathrm{qt} \mathrm{ha}^{-1}\right)$ were obtained during the first year (2013) in the second sowing time (June 11,2013$)$ at $6 \mathrm{~kg} \mathrm{ha}^{-1}$ seeding rate. Therefore, it can be recommended that the lower seed rate $(6 \mathrm{~kg}$ ha$\left.{ }^{1}\right)$ sown at 3 weeks after commencement of the main rain was produced better herbage DM (18.7 ton ha-1) and seed yields $\left(6.37 \mathrm{qt} \mathrm{ha}^{-1}\right)$ and was favorable for Bako area and similar agro ecologies.
\end{abstract}

Keywords: Dry matter, herbage yield, sowing time, seed rate

DOI: $10.7176 /$ JAAS/70-01

Publication date: January $31^{\text {st }} 2021$

\section{Introduction}

The low production and productivity of Ethiopian livestock is a result of several limiting factors among which feed is the major one. For the country as a whole the existing feed does not meet the amount required by livestock. In most parts of the country natural grasslands are confined to degraded shallow upland/highland, fallow crop lands and soils that cannot be successfully cropped due to physical constraints such as flooding and water logging. They are low yielding and their production is insufficient and grazing conditions are only favorable for four to five months per year (Alemayehu et al., 2016). Residues from cereals are the main source of animal feed but these are low in protein and have poor digestibility. Fodders are the most valuable and cheapest source of feed for livestock having rich source of metabolizable energy, nutrient elements, carbohydrates and protein. The production of adequate quantities of good quality dry season forages to supplement crop residues and pasture roughages is the only way to economically overcome the dry season constraints affecting livestock production. Generally, good quality forage is high in protein and digestible nutrients, and low in fiber and lignin. Also, animal performance is a better indicator of forage quality (Ahmed A. Bakhashwain, 2010).

Brachiaria decumbens (Signal grass) is a highly productive tropical grass that is widespread in different agroecologies due to its adaptation to a wide range of soil types and environments including infertile acid soils with low $\mathrm{pH}(<3.5)$ and climates ranging from tropical to sub-tropical (Keller-Grein, et al., 1996, Bogdan, A., 2012). It is able to withstand short-term drought conditions by re-allocation of biomass and adjustment of growth rates' resulting in no significant differences in biomass yield but is highly susceptible to water logging and can only tolerate flooding for a few days(Loch, D.S, 1977 and Guenni, O., et al., 2002). In the past three decades, extensive research has been done at BARC to evaluate the adaptability and performance of different forage species under different agro-ecological zones particularly in the western region with the special focus on the mandate areas of the center. Among these forage species Brachiaria decumbens is one of the potential grass that was adopted at BARC and was expected to solve the severe feed deficit that the region is presently facing. However, information on the production packages (agronomic practices); like sowing date and seed rate are not yet determined and lagging behind.

Germination is a natural process that occurred during growth period of seeds in which they meet the minimum condition for growth and development (Sangronis et al., 2006). Germination of tropical grasses and legumes is typically low mostly due to dormancy restriction (Antonio sotomay \& pitman, 2001), which might be improved through planning at proper planting time. Date of planting has a significant role in harvesting maximum yield from 
a plot of land. Besides other agronomic management recommendations, seeding rate and planting date play a great role in harvesting maximum yield from a plot of land (Tessema Zewudu.1996). Therefore, the objective of the current study was to determine the suitable seeding rate and a specific planting time to optimize Bracharia decambus yield.

\section{Materials and Methods}

\section{Description of the Study Area}

The experiment was conducted at BARC which is found at 1650 m.a.s.1, $7^{\circ} 17^{\prime} 12.5^{\prime \prime} \mathrm{N} ; 38^{\circ} 25^{\prime} 47.5^{\prime \prime} \mathrm{E}$ and $250 \mathrm{~km}$ west of Finfine. During the growing seasons of 2013, 2014 and 2015, the annual rain fall were 1431, 1067 and $944 \mathrm{~mm}$, respectively with the average mean value of $1147 \mathrm{~mm}$. Mean value of the temperature recorded was $21^{\circ} \mathrm{C}$ with a range of 13 to $29^{\circ} \mathrm{C}$ (BARC meteorological station 2013-2015). Dominant soil types are Nitosols with fertile alluvial soils in valley bottoms. The area is known for its mixed crop livestock farming system in which cultivation of maize, teff (Eragrostis tef), noug (Guizotia abyssinica), sorghum, finger millet are the major crops in their order of importance (BARC, 2003). Major animal feed resources are natural pasture, crop residues and improved forage species. Cattle and sheep are important livestock species abundantly found in the areas.

\section{Rain fall distribution during the experimental period (2013-2015)}

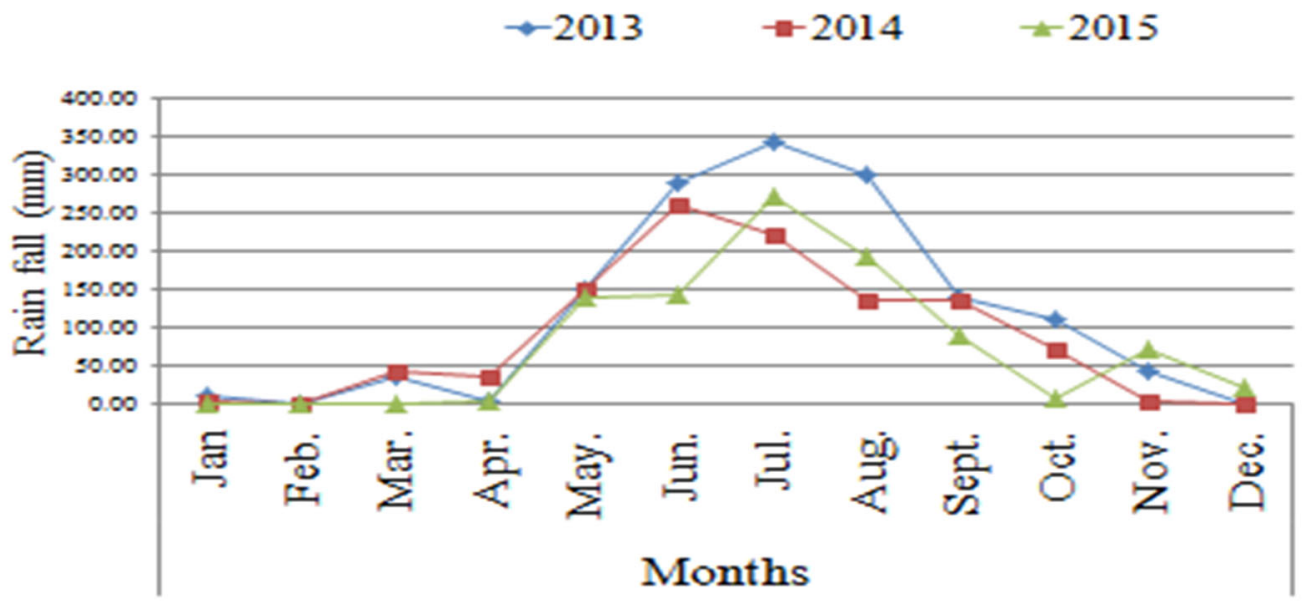

Figure 1: Rain fall distribution of the tested environment during the experimental period (2013-2015)

Figure 2: Average temperature across the study period (2013-2015)
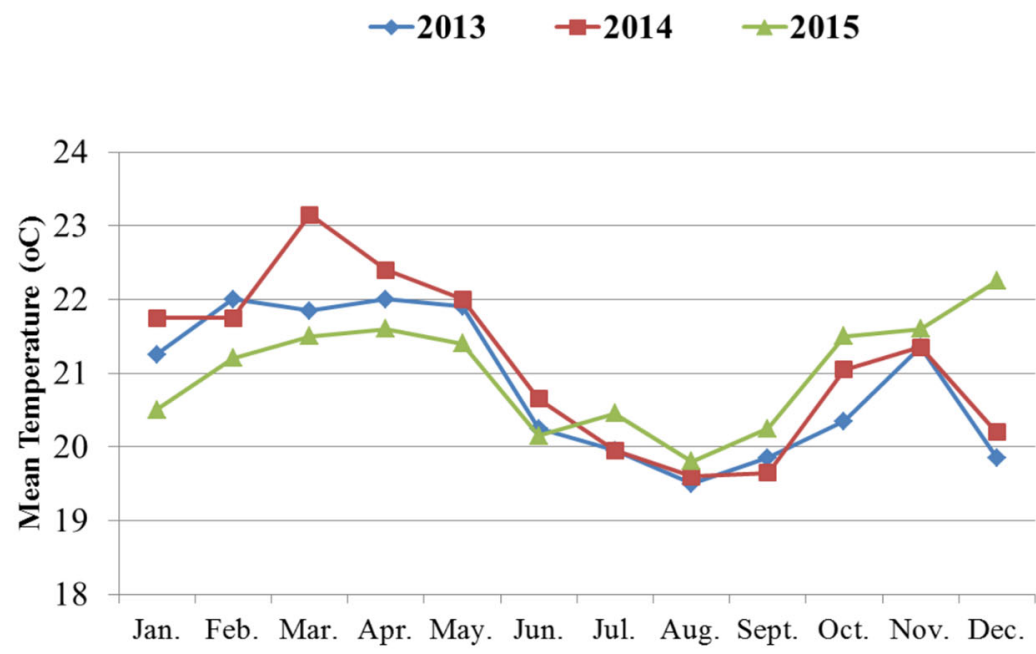

\section{Months of the year}

Figure 2: Average temperature scored across the study sites during the experimental period (2013-2015) 


\section{Treatment Description and Experimental Design}

The treatments consists of four sowing dates ( 1 week, 3 weeks, 5 weeks and 7 weeks) after onset of main rain and four seed rates $\left(6,8,10\right.$ and 12) $\mathrm{kg} \mathrm{ha}^{-1}$ of Brachiaria decumbens. Randomized complete block design in factorial arrangement with three replications was used. The seed was planted on $12 \mathrm{~m}^{2}$ plots $\left(3 \mathrm{~m}^{*} 4 \mathrm{~m}\right)$ having six rows with intra-row spacing of $30 \mathrm{~cm}$ and $1 \mathrm{~m}$ distance between rows. Crop management practices (hoeing, weeding etc.) were practiced as required. Both DAP and Urea at the rate of $100 \mathrm{~kg} / \mathrm{ha}$ with split application was used followed during the first season. Data from herbage yield, seed yield and other important agronomic parameters were measured as dependent variables. For sampling $200 \mathrm{gm}$ fresh biomass were taken and partial DM contents were determined by oven drying at $65 \mathrm{oC}$ for 72 hours to a constant weight. All agronomic parameters were subjected to ANOVA using SAS (SAS, 2008) software.

\section{Results and Discussion}

The results of the analysis of variance indicated significant effects of Bracharia decumbas sowing date and seeding rate on most of the tested variables (Table 1). Seeding rate by planting time interaction effect was highly significant $(\mathrm{p} \leq 0.01)$ for herbage DM yield and seed yield. However, no significant differences were observed for plant height, plot cover and vigorousity. The planting time mean square was significant for all parameters considered. Similarly, highly significant $(p \leq 0.01)$ variations between the years for almost all parameters except vigorousity which was showed non-significant results. This might be due to the variations of rainfall distribution during the experimental period. The mean square of seeding rate also showed a significant effect on DM yield, seed yield and plot cover, however, non-significant differences were observed for plant height and vigorousity.

Table 1: Mean squares of ANOVA for seeding rate and planting date of Bracharia Decumbas at BARC.

\begin{tabular}{lllllll}
\hline Source of variation & DF & \multicolumn{5}{c}{ Mean squares } \\
\cline { 3 - 7 } & & DMY & SY & PH & PC & Vig \\
\hline Block & 2 & 4.569 & 6.93 & 10.82 & 21.88 & 3.5625 \\
Sowing_date & 3 & $41.466^{* *}$ & $4.2431^{*}$ & $108.14^{*}$ & $6.465^{*}$ & $3.7292^{*}$ \\
Seeding_rate & 3 & $13.772^{*}$ & $2.6755^{*}$ & 41.92 & $4.187^{*}$ & 1.0625 \\
Year & 2 & $441.419^{* *}$ & $415.64^{* *}$ & $10364.34^{* *}$ & $26.271^{* *}$ & 0.00 \\
Sowing_date *seedingrate & 9 & $25.426^{* *}$ & $5.5306^{* *}$ & 27.98 & 0.763 & 0.8403 \\
Sowing_date *.year & 6 & 4.341 & 0.6537 & 29.39 & 1.215 & 0.00 \\
Seeding_rate.*year & 6 & 1.478 & 0.3241 & 18.35 & 0.354 & 0.00 \\
Sowing_date *seedingrate*year & 18 & 1.069 & 1.379 & 37.49 & 1.249 & 0.00 \\
Error & 94 & 3.391 & 0.9687 & 33.95 & 1.499 & 0.754 \\
\hline
\end{tabular}

Where, ${ }^{*}, * *$ : Significant at 5\% and 1\%, respectively. DF: Degree of freedom, DMY: herbage yield in Dry mater bases, SY: Seed yield, PH: Plant height, PC: Plot cover, Vig: Vigourisity.

\section{Effects of sowing date}

Planting date was affected virtually all of the yield and agronomic parameters (DM yield, seed yield, plant height, plot cover and plant vigor). Similarly, experimental periods were shown significant $(\mathrm{p}<0.01)$ effect on herbage DM yield, seed yield, plant height and plot cover, but non-significant results was observed for plant vigor (Table 1). This might be related to climatic conditions mainly temperature and rain fall of the study area during planting season.

\section{Effects of seeding rate}

Seeding rate significantly $(\mathrm{p}<0.05)$ influenced herbage DM yield, seed yield and above ground cover. On the other hand, seeding rate was not significantly affected plant height and plant vigor in this study (Table 1).

\section{Seeding rate and Sowing date interaction}

Interestingly, there was a significant interaction between seeding rate and planting time on herbage dry matter yield and seed yield concurrently. The highest herbage dry matter yields and seed yield (18.67 ton ha $\left.{ }^{-1}\right)$ and $(6.37$ qt $\mathrm{ha}^{-1}$ ), respectively were obtained from seeding rate of $6 \mathrm{~kg} \mathrm{ha}^{-1}$ that planted at three weeks after the commencement of main rainy season (Table 2). This indicated that lower seed rate can provide optimum yields when sufficient moisture and moderate temperature obtained. This is probably due to climatic condition of the study area i.e. under perceived optimal conditions for plant emergence (e.g. ample soil moisture and appropriate soil temperature). Such scenario is suitable for the crops to get the chance to germinate quickly. As germination getting faster, optimum production would be expected.

Surprisingly in this study, lower seeding rate $\left(6 \mathrm{~kg} \mathrm{ha}^{-1}\right)$ has been produced optimum herbage dry matter yield and seed yield comparing with the other seeding rate. On the other hands, there was no significant interaction were observed on plant height, plot cover and plant vigor. Planting Bracharia seed at one week after main rain commencement at higher rate $\left(12 \mathrm{~kg} \mathrm{ha}^{-1}\right)$ was produced relatively better herbage dry matter yield (13.86 ton ha- 
${ }^{1}$ ). This was probably increasing the seeding rate at first rain drop could resulted moderate herbage yield and seed yield production than lower seed rate in this study.

Table 2. Interaction effects of seeding rate and Sowing date of Bracharia Decumbas at BARC

\begin{tabular}{|c|c|c|c|c|c|}
\hline \multirow{2}{*}{$\begin{array}{l}\text { Sowing date } \\
\text { Herbage DM yield (ton/ha) }\end{array}$} & \multicolumn{4}{|c|}{ Seeding rate $\left(\mathrm{Kg} \mathrm{ha}^{-1}\right)$} & \multirow[t]{2}{*}{ Mean } \\
\hline & 6 & 8 & 10 & 12 & \\
\hline 1 week after main rain fall & $10.9^{\mathrm{e}}$ & $13.58^{\mathrm{bcd}}$ & $12.04^{\mathrm{de}}$ & $13.86^{\mathrm{bc}}$ & 12.60 \\
\hline 3 week after main rain fall & $18.67^{\mathrm{a}}$ & $14.61^{\mathrm{b}}$ & $12.72^{\mathrm{cd}}$ & $13.39^{\mathrm{bcd}}$ & 14.85 \\
\hline 5 week after main rain fall & $14.6^{\mathrm{b}}$ & $12.38^{\text {cde }}$ & $13.31^{\mathrm{bcd}}$ & $13.76^{\mathrm{bcd}}$ & 13.51 \\
\hline 7 week after main rain fall & $12.32^{\text {cde }}$ & $13.06^{\mathrm{bcd}}$ & $12.36^{\text {cde }}$ & $12.52^{\text {cde }}$ & 12.57 \\
\hline $\operatorname{LSD}(0.05)$ & 1.72 & & & & \\
\hline $\mathrm{CV} \%$ & 13.8 & & & & \\
\hline \multicolumn{6}{|l|}{ Grain yield (Qt ha-1) } \\
\hline 1 week after main rain fall & $4.545^{\mathrm{bcd}}$ & $3.9^{\text {cde }}$ & $3.827^{\mathrm{cde}}$ & $3.911^{\mathrm{cde}}$ & 4.05 \\
\hline 3 week after main rain fall & $6.374^{\mathrm{a}}$ & $4.431^{\mathrm{bcd}}$ & $3.461^{\mathrm{e}}$ & $5.1^{\mathrm{b}}$ & 4.84 \\
\hline 5 week after main rain fall & $3.756^{\text {cde }}$ & $5.093^{\mathrm{b}}$ & $4.281^{\text {bcde }}$ & $4.118^{\text {cde }}$ & 4.31 \\
\hline 7 week after main rain fall & $3.972^{\text {cde }}$ & $4.537^{\text {bcd }}$ & $4.664 b^{c}$ & $3.691^{\mathrm{de}}$ & 4.22 \\
\hline $\mathrm{LSD}(0.05)$ & 0.9212 & & & & \\
\hline CV \% & 22.6 & & & & \\
\hline
\end{tabular}

Variation in seeding rate had less pronounced effect on herbage dry matter yield and seed yields than did variation in planting time (Table 2). The responses to seeding rate $\mathrm{x}$ sowing date were different in each year. The highest average herbage yields (16.18 ton $\mathrm{ha}^{-1}$ ) were obtained during the first year (2013) while 13.81 and 10.16 ton $\mathrm{ha}^{-1}$ ) obtained during the $2^{\text {nd }}$ and $3^{\text {rd }}$ year respectively. Similarly, seed yields followed the same trend observed on herbage dry matter yields. In view of that, an average seed yield of $\left(6.96,4.95\right.$ and 1.16) qtha ${ }^{-1}$ were produced during the 2013, 2014 and 2015 cropping season respectively (Table 3). Generally, at first year of growing stage, optimum production was obtained and as the crop getting older the herbage dry matter yields and seed yield was radically decreased.

\section{Impact of experimental duration/years}

Interaction effects of seeding rate by sowing date on herbage dry matter yields and seed yields were significantly $(\mathrm{p}<0.01)$ impacted by experimental year. As a result, during the first year (2013) maximum herbage dry matter yield $\left(22\right.$ ton $\left.\mathrm{ha}^{-1}\right)$ in the second planting time (June 11, 2013) at $6 \mathrm{~kg} \mathrm{ha}^{-1}$ of seeding rate (i.e. $3 * 6$ planting time by seeding rate interaction) and lower performing $\left(15\right.$ ton ha $\left.{ }^{-1}\right)$ at the same junction during the $3^{\text {rd }}$ year of the experimental period (fig.3). The same trends were followed for seed yield in this study (figure 4). This result is probably due to less competition with weeds, which destroyed the germinated weeds after the initial preparation of the area for the first sowing time, as well as due to climatic conditions encountered in that period.

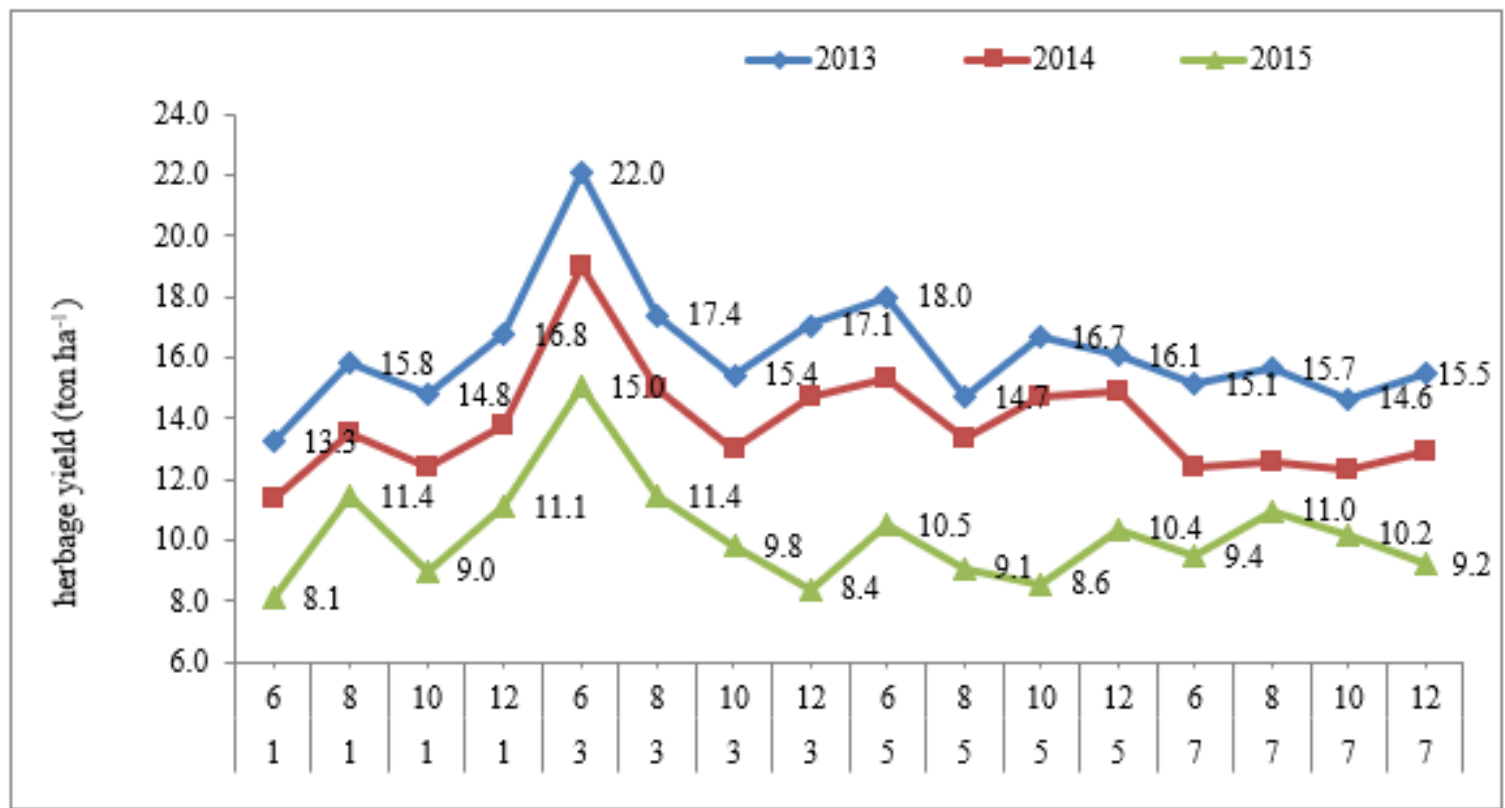

Figure 3: Interaction effects of seeding rate and sowing date on DM yield (ton ha ${ }^{-1}$ ) of Bracharia decumbas across years $(2013-2015)$ 


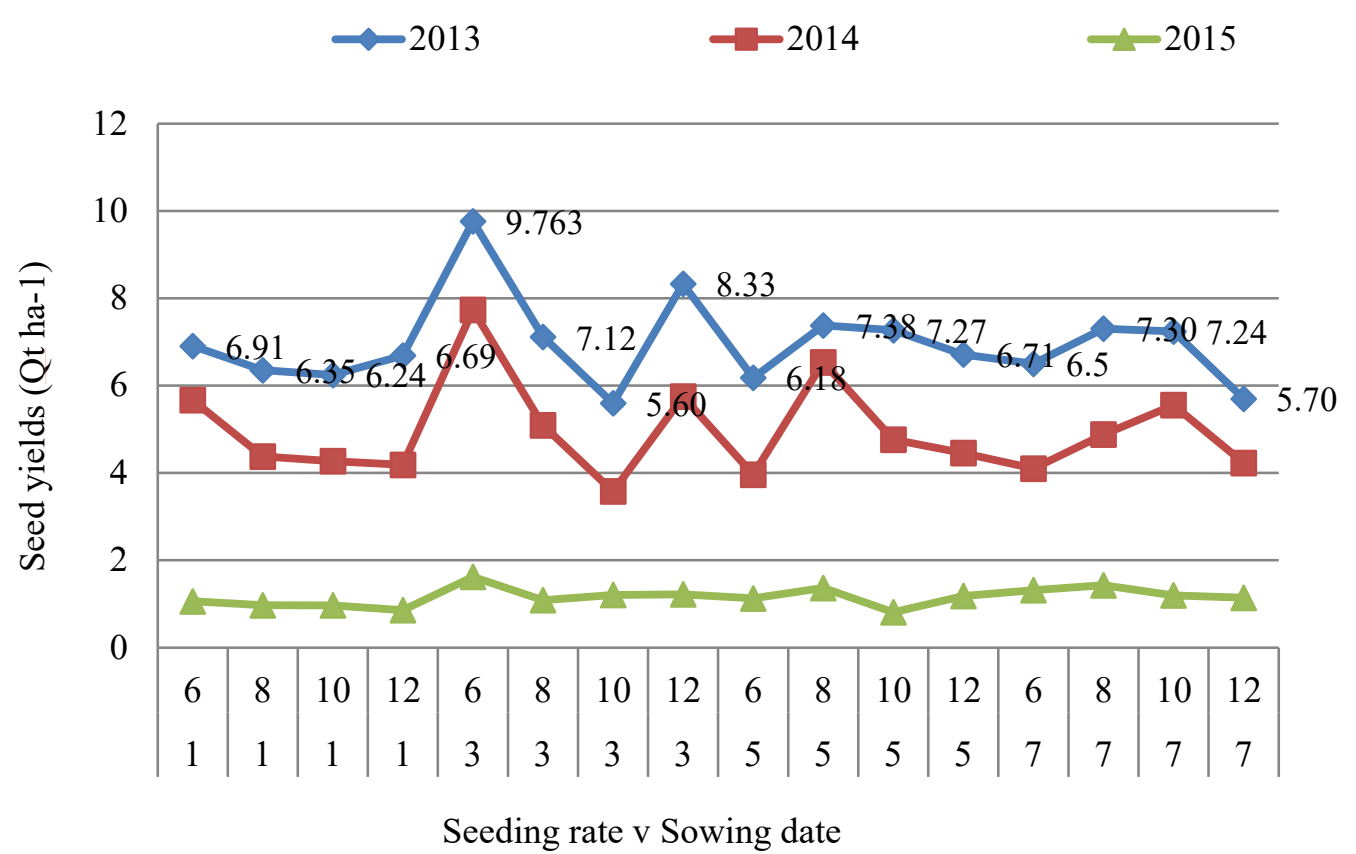

Figure 4: Interaction effects of seeding rate and sowing date on seed yield (ton ha ${ }^{-1}$ ) of Bracharia decumbas across years (2013-2015)

\section{Conclusions and Recommendation}

The current study showed the interaction effect of planting date and seeding rate was significantly affected both herbage DM and SY, with better harvests taken $6 \mathrm{~kg} \mathrm{ha}^{-1}$ planted at 3 weeks after onset of main rain fall. This might be due to the existence of ample soil moisture and appropriate soil temperature, which may be created optimal condition for plant emergence. It also concluded that the highest seed rate treatment groups, 8,10 and $12 \mathrm{~kg} \mathrm{ha}^{-1}$ during the 3-7 weeks onset of rain fall produced lower yields. This could be due to a higher population of plants on a single plot of land resulting in higher competition for soil resources.

In this study experimental year was highly affected production of both herbage dry matter and seed yields, in which the first year (2013) exhibiting superior herbage DM yields (22 ton ha-1) and seed yield $\left(9.76 \mathrm{qt} \mathrm{ha}^{-1}\right)$ in the second sowing time (June 11, 2013) at $6 \mathrm{~kg} \mathrm{ha}^{-1}$ seeding rate. Hence, as the age of the perennial grasses getting older resulted in significant yield reduction and needs remarkable improvements. Therefore, it can be recommended that the lower seed rate $\left(6 \mathrm{~kg} \mathrm{ha}^{-1}\right)$ sown at 3 weeks after commencement of the main rain was produce better herbage DM (18.7 ton $\left.\mathrm{ha}^{-1}\right)$ and seed yields $\left(6.37 \mathrm{qt} \mathrm{ha}^{-1}\right)$ and was favorable for Bako area and similar agro ecologies.

\section{References}

Ahmed A. Bakhashwain, 2010. Fodder Yield and Quality of Rhodes Grass-Alfalfa Mixtures as Affected by Sowing Rates in Makkah Region. Met., Env. \& Arid Land Agric. Sci., Vol. 21, No.1, pp. 19-33.

Alemayehu M., Getnet A., Gezahagn K. and Fekede F., 2016. Review on the Evolution of Forage Seed Production in Ethiopia: Experiences, Constraints and Options. Academic Research Journal of Agricultural Science and Research, Vol. 4(6), pp. 231-240.

Antonio sotomay \& pitman, 2001.Tropical forage plants development and Use .CRC (2001) press LLC,BocaRaton,London,New York, Washington D.C.

Bogdan, A., 2012. Tropical Forages. Available online: http://www.tropicalforages.info/key/Forages/Media/ Html/Brachiaria_brizantha.htm (accessed on 18 October 2012). Tropical Pasture and Fodder Plants; Longman: Essex, UK, 1977.

Guenni, O.; Marín, D., Baruch, Z. 2002. Responses to drought of five Brachiaria species. I. Biomass production, leaf growth, root distribution, water use and forage quality. Plant Soil 2002, 243, 229-241.

Keller-Grein, G., Maass, B.L., Hanson, J. 1996. Natural variation in Brachiaria and exisiting germplasm collections. In Brachiaria: Biology, Agronomy and Improvement; Miles, J.W., Maass, B.L., do Valle, C.B., Eds.; CIAT: Cali, Colombia, 1996; pp. 16-42.

Loch, D.S.1977. Brachiaria decumbens (signal grass)—A review with particular reference to Australia. Trop. Grassl. 1977, 11, 141-157. 
Sangronis, E., Rodriguez, M., Cava, R. \& Torres, A. 2006. Protein quality of germinated Phaseolus vulgaris. European Food Research and Technology 222: 144-148.

Tessema Zewudu. 1996. Forage yield performance of different perennial grass/legume mixtures in the North West Ethiopia. Proceedings of the fourth national conference of Ethiopian society of Animal production, April 1819, 1996, Addis Ababa, Ethiopia. 